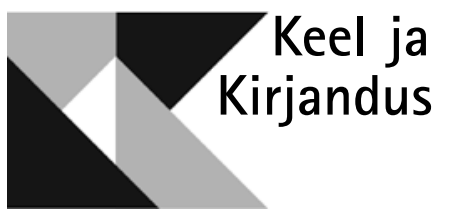

\title{
KIRJANDUSTEADUSE KOLMAASTAK
}

\author{
Andmebaasipõhine vaatlus*
}

KADRI TÜÜR, ELLE-MARI TALIVEE

\section{Sissejuhatus}

$\mathrm{R}$ ahvuskultuuri ilmingute järjepidev seire on kultuuri kestmiseks vajalik autokommunikatsiooni mehhanism. Kirjandusteaduse ülevaade on eeldatavasti üks viis saada lähemat teavet ühes olulises vaimse tegevuse valdkonnas toimuvast ning teha järeldusi meie kultuuri kui terviku käekäigu kohta.

Käesoleva käsitluse ajaliseks raamiks on aastad 2010-2012. Kolm aastat on just sellise pikkusega aeg, mis Eesti Teadusfondi teadusrahastuse süsteemi juures enam-vähem võrdub ühe grandi elutsükliga. Seoses üleminekuga uuele rahastusmudelile on kahtlemata asjakohane heita põgus tagasipilk möödunud kolmele aastale, et näha, milliseid tulemusi andis see periood meie kirjandusteaduses. Mõne aasta pärast on loodetavasti põhjust tulemusi võrrelda nendega, mis saadakse Eesti Teadusagentuuri poolt juurutatava IUT-ide ja PUT-ide süsteemi ${ }^{1}$ raames. Pikema kui üheaastase perioodi vaatluse alla võtmine on põhjendatav ka kaasaegse rahvusvahelise publitseerimispraktikaga,

${ }^{*}$ Soovime tänada Tartu Ülikooli raamatukogu töötajaid Anneli Seppa ja Kristina Paid, kellelt saime head nõu ja selgitusi ESTER-i ja ISE otsingute tegemisel, samuti Eesti Maaülikooli teadurit Hannes Pehlakut eksporditud kirjete tabeliks konverteerimise alase oskusteabe jagamise eest.

${ }^{1}$ Institutsionaalsed ja personaalsed uurimistoetused; lähemalt vt etag.ee/rahastamine. 
kuna sageli ei ilmu kõrgelt koteeritud eelretsenseeritavad artiklid ajakirjade ja kogumike erinevaid toimetamisfaase läbides mitte nende kirjutamisega samal aastal, vaid aasta-paar hiljem. Ühel aastal üllitatud uurimuste dünaamika ei pruugi peegeldada nende valmimisprotsessi pikkust ega intensiivsust. ${ }^{2}$

Rahvusvaheliste akadeemiliste publikatsioonide seas võib selliste vormiliselt ja temaatiliselt piiritletud ülevaateartiklite sõsaržanriks pidada erialakirjanduse ülevaateartiklit (literature review), kus loetletakse esinduslik hulk mingi uurimisvaldkonna olulisemaid publikatsioone (kuid valim ei ole ajaliselt ega geograafiliselt piiratud). Meie ülesanne on anda võimalikult kattev pilt eesti kirjanduse uurimisega seotud teaduspublikatsioonidest vaatlusalusel ajavahemikul. Oleme keskendunud kirjalikele tekstidele ja jätnud vaatluse alt kõrvale üritused (konverentsid, seminarid, suvekoolid), mis kahtlemata siinset kirjandusteadust elavdavad, kuid eeldatavasti kajastub nende väljund varem või hiljem artikli- ja kogumikukirjetena erinevates andmebaasides.

Kui varasemate kirjandusteaduse ülevaateartiklite autorid on objekttekste grupeerinud temaatiliselt, siis käesolevas ülevaates lähtume pigem formaalsetelt alustelt, liigendades ilmunud käsitlusi nende vormi (ja vaikimisi muidugi ka klassifikaatori) järgi. ${ }^{3}$ Teise olulise formaalsuse ülevaate koostamise lähtekohtades tõime sisse seeläbi, et ei püüdnud hakata ise filosofeerima teemal „mis on kirjandusteadus ja mis seda ei ole”, vaid võtsime valimi koostamisel aluseks tänavu viieteistkümnendat aastat kasutuses oleva eesti teadusraamatukogude elektroonilise ühiskataloogi ESTER ning selle noorema õekese, artiklite andmebaasi ISE. Juhindusime asjakohaste publikatsioonide otsinguis neis andmebaasides kasutatavatest märksõnadest ning universaalsetest detsimaalklassifikaatoritest (UDK). Nii soovisime vähendada allikmaterjali valiku subjektiivsust ning ühtlasi tõsta esile seda suurt tööd, mida meie bibliograafid ilmuvate tekstide kataloogimisel igapäevaselt teevad. Kasu andmebaaside testimisest võib osutuda mõlemapoolseks, sest temaatiliste kogumite päringuid kasutajavaates (raamatukogutöötajate käsutuses on selleks mõnevõrra komplekssemad otsivahendid) ei tehta just sageli ning selle tegevuse käigus saadud kogemused on loodetavasti abimaterjaliks andmekogude edasisel arendamisel ja sisuga täitmisel. Analüüsifaasis ei pääsenud me siiski otsingute kordamisest ning subjektiivsetest hinnangutest artiklite teemasse sobivuse osas; üldise otsinguga ning käsitsi selekteerimise abil saadud tulemused on tekstis üksteisest eristatud.

Peamiste numbriliste tulemustena võib sedastada, et vaadeldaval kolmel aastal on eesti kirjandusega seotud teaduslikke käsitlusi ilmunud ca 70 raamatu ja 500 artikli kujul. Kuna tegemist on üha enam interdistsiplinaarsuse suunas avaneva valdkonnaga, tuleb kirjandusteadusse puutuvaid uurimusi otsida paljudest erinevatest humanitaarväljaannetest ning tulemus ei pruugi siiski saada ammendav. Esile tahame tõsta institutsionaalses koostöös valminud uurimusi ja kogumikke, sest just sellisel viisil tekib erialaseks edenemiseks nii vajalik diskussioon (ja parimal juhul ka sünergia).

Järeldused, mida võime oma töö tulemuste põhjal teha, puudutavad peamiselt tehtud töö kommunikatiivsust ning selle tõstmise võimalusi. Uurimuste võrgus kättesaadavaks tegemine on oluline, sest tänapäeva noorema uurija

\footnotetext{
${ }^{2}$ Sedasama tõdeb Tiit Hennoste (2008: 233) 2007. aasta kirjandusteaduse ülevaates.

${ }^{3}$ Kui Hennoste oma ülevaates väljendab veel protesti säärase „tõuaretuse” suhtes (2008: 246) ja Anneli Mihkelev eelmist ülevaadet kirjutades küsimust ei käsitle (Mihkelev 2010), siis seekord nendime mängureegleid ja analüüsime ühtlasi möödaminnes nende toimivust.
} 
juurde pelga paberkandjaga enam ei ulatu. Eeskuju andev võiks siin olla ajakirja Akadeemia praktika, mille numbrid on leitavad Rahvusraamatukogu digitaalarhiivi DIGAR vahendusel. Sel juhul ei lasu väljaandel endal vastutust ülal pidada tehniliselt suhteliselt keerukat arhiveerimis- ja esitluskeskkonda; samuti on tagatud täistekstide linkimine ESTER-i ja ISE kataloogikirjetega, mis lisab oluliselt kasutajamugavust.

\section{Materjal ja metoodika}

Rahvuskultuurilise relevantsiga tekstitoodangu aastaülevaadetes ${ }^{4}$ domineerivad luule, proosa ja lastekirjanduse žanriülevaated, kuid leidub ka sissevaateid draamasse, ulmesse, reisikirjandusse ning isegi luustikuleidudesse. Kirjandusteaduse ja -kriitika ülevaated on mõnel aastal ilmunud eraldi, mõnel juhul on neid käsitletud ühtsesse raami mahtuvate nähtustena. Piiri on tõepoolest raske tõmmata. Kuna päevalehtedes ilmuvate kirjandusaineliste tekstide maht on suur ning sageli on tegemist pigem raamatututvustuste kui süveneva kriitikaga, oleme selle materjali vaatluse alt kõrvale jätnud (ehkki allpool kirjeldatud otsingumetoodika abil ilmub ta vältimatult otsingutulemustesse). Küll aga oleme pööranud tähelepanu kirjandusteaduslike publikatsioonide kohta perioodikas ilmunud arvustustele, sest see aitab omakorda teha mõningaid järeldusi avalikkuses enam resonantsi tekitanud uurimuste sisu ja iseloomu kohta.

Kirjandusteadusega piirnevate erialadena jäävad siin vaatluse alt välja teatriteadus ja folkloristika, mis ajaloolistel põhjustel on meil seisnud kirjandusteadusele ja -loole suhteliselt lähedal. Küll aga on hõlmatud võrdlev kirjandusteadus ja kirjandussemiootika, mis erinevad „eesti kirjandusteadusest” kas materjalivaliku laiema ulatuse või erialaspetsiifilise metodoloogia poolest, kuid tegelevad siiski olemuslikult sama asja - kirjanduslike, s.t kunstilise ambitsiooniga kirjalike tekstide analüüsimisega. Keeleteadus on tänapäeval kirjandusteadusest juba sellistesse kõrgtehnoloogilistesse kaugustesse eemaldunud, et nende kahe valdkonna artiklid omavahel suuresti ei suhestugi.

Ei teoreetilised ega praktilised argumendid anna alust kitsendada eesti (rahvuslikust) kirjandusteadusest kõneledes vaatlusaluste uurimuste hulka nende autorite passijärgse rahvuse või rahvastikuregistrijärgse sissekirjutuse alusel. ${ }^{5}$ Lisada tuleks mujal tehtud uurimused, mis käsitlevad Eestiga seotud kirjandust. Riigipiiride ületamist näikse soosivat ka riiklikud mehhanismid, sest enamik praegusi teadusrahastuse meetmeid toetab teadlasmobiilsust ja rahvusvahelisi teadusüritusi ning üldine teaduspoliitika väärtustab rahvusvahelistes ajakirjades publitseerimist. Nii rikastavad meie kirjandusteadust ühtaegu estofiilsed prantslased ja Eestist Brasiilia kirjandust uurima sirutunud doktorandid. Meie asi on seda panust tunnustada ja omalt poolt kaasa aidata kogu selle mitmekesisuse lõimimisele kohalikku teadmusringlusse.

Eelnevast lähtudes oli meie põhjendatud ülesandeks kõigepealt hankida võimalikult täielik ülevaade kirjandusteaduse vallas ilmunust üleüldse, et

${ }^{4}$ Sõnaotsing „aastaülevaated” ise.elnet.ee-s annab tulemuseks 59 artiklit aastatest 1996-2013.

${ }^{5}$ Sarnasel teemal on Anneli Mihkelev (2010: 280) eelmist ülevaadet kirjutades leidnud: „Nii et järgnevas kirjutises pole vaatluse all mitte eesti kirjandusteadus, vaid kirjandusteadus Eestis." 
opereerida ka mingite arvudega. Selliseks koondotsinguks pakuvad võimalusi raamatukogude e-kataloog ESTER ning artiklite andmebaas ISE. Vaatlusalune materjal jaguneb raamatuteks ning üksikartikliteks vastavalt sellele, millist laadi tekste kummaski andmebaasis registreeritakse. ESTER-i olulisemad teavikulaadid kirjandusteaduse osas on raamatud, jätkväljaanded ja käsikirjad. Raamatute hulka kuuluvad nii monograafiad kui ühe autori artiklikogumikud, samuti ühtede kaante vahel avaldatud temaatilised uurimuste kogumid. Jätkväljaandeid eristab ajakirjadest eeskätt nende aperioodilisus ning madalam klassifikaator. Käsikirjadena kajastuvad kataloogis muuhulgas bakalaureuse- ja magistritööd. Need jätsime vaatluse alt välja, mõeldes nii käesoleva ülevaate mahupiirangutele kui ka asjaolule, et paljud neist töödest on juba Keele ja Kirjanduse ringvaate rubriigis tutvustamist leidnud. Märksõnadega „teesid” ja „konverentsikogumikud” (mis teaduspraktikas ei ole tegelikult kaugeltki kattuvad mõisted) varustatud kirjed jäid samuti lähema vaatluse alt välja, sest seal avaldatu kujutab endast enamasti pigem etüüdikesi kui teaduspublikatsioone.

ISE kordab detailsemalt ESTER-i kaudu leitut artiklikogumike osas, kuna seal on igale kogumikuartiklile tehtud omaette kirje. See on eriti tänuväärne ühe autori artiklikogumike puhul, sest võimaldab heita pilgu teose sisukorda ilma seda otseselt kätte võtmata. Samuti leidub artiklikirjetes viide iga teksti esmailmumiskohale, kui see olemas on. Sel moel saab kogumike sisuga - vähemalt osaliselt - tutvuda ka sõrmi arvutiklahvidelt tõstmata, kuna järjest enam kodumaiseid humanitaarajakirju on asunud oma arhiive võrgus kättesaadavaks tegema. Lisaks kogumikele registreeritakse ISE-s kõik Eestis ilmuvates ajakirjades avaldatud artiklid, valikuliselt ka Eesti teadlaste jaoks olulisemates välisajakirjades ilmunud publikatsioonid (nt Journal of Baltic Studies). ISE väljaannete tüpoloogia on lakooniline: ajakiri, ajaleht, kogumik. Eesti kultuuriajakirjanduse eripäraks on muuhulgas see, et otsingust ajalehti välistades jääks ülevaatesse sisse suur lünk Sirbi koha peal, kuna paljusid seal avaldatud kirjandusteemalisi kirjutisi võib kõhklusteta pidada uurimusteks. Sestap otsisime iga kategooriat eraldi ning sorteerisime saadud tulemusi hiljem inimtöojoũu ja intellektuaalse pingutuse varal. Artiklitüüpide nomenklatuur ISE-s on siiski märksa avaram, alates artiklist, arvustusest, dokumendist ja eluloost ning lõpetades nekroloogi, nimekirja, pildi ning sõnumiga. Artikli tüübile me esmases otsingus piirangut ei seadnud; hilisem sorteerimine toimus samuti osaliselt käsitsi. Lühidalt - materjali kogumise protsessi meil täiel määral automatiseerida ei õnnestunud.

Nüüd aga ka metoodikast. Et eksperiment kirjandusteaduse ülevaatega oleks korratav ja annaks adekvaatsema tulemuse kui pelgalt meie subjektiivsed teadmised, sooritasime nimetatud andmebaasides mitmeid päringuid. Eeldasime esialgu, et kirjandusteadus, teadusharu, mis „Eesti keele seletava sõnaraamatu" järgi uurib ilukirjanduse eripära ja arenemist ning hindab tema kunstiväärtusi, on märksõnastamisel kasutusel katusmõistena. Otsingusse tahtnuks panna päringuks esiteks ja kõikekatvalt kirjandusteaduse. Kontrollimisel selgus aga, et kataloogis alustatakse pigem hierarhiliselt peenemaist määratlusist ning kirjandusteaduseni ei pruugi märksõnastamine välja jõudagi, sest tegu on iga konkreetse kirje seisukohast liiga üldise terminiga. ${ }^{6}$

\footnotetext{
${ }^{6}$ A. Sepp ja K. Pai, suuline konsultatsioon 5. III 2013.
} 
Märksõnaotsinguks aitab kõige paremini valmistuda „Eesti märksõnastik”, mis on „kõiki ainevaldkondi hõlmav tesauruse struktuuriga märksõnastik raamatute, perioodikaväljaannete, artiklite, nootide, helisalvestiste, kaartide jm teavikute eestikeelseks märksõnastamiseks ja infootsinguks". ${ }^{7}$ Selle kohaselt kuulub „kirjandusteadus” üldmõiste „filoloogia” alla ühes keeleteaduse, folkloristika, klassikalise filoloogia, paleograafia, tekstoloogia ja tõlketeooriaga. Valides „kirjandusteaduse”, välistame suure tõenäosusega niisiis kõik eelloetletud, ehkki teoreetiliselt on võimalik, et üht publikatsiooni märgendatakse rohkem kui ühe loetletud kategooria abil. „Kirjandusteadusest” kitsamat, s.t mingist aspektist piiritletumat valdkonda määratlevad kirjandusajalugu, -kriitika, -semiootika, -teooria, narratoloogia, poeetika, tekstiteooria, aga ka Vene vormikoolkond ja võrdlev kirjandusteadus (lisaks on veel hulk „seotud” märksõnu, mille olemusse süvenemine jäägu edaspidiseks). Kuidas aga nende märksõnade mõistemahtu üksteise suhtes piiritleda? Mis on -teadus, -teooria, -kriitika, -ajalugu? Kui valime välja mõned neist, siis mis on see, mis jääb välja või kõrvale? Et neile küsimustele selget vastust saada, oleksime pidanud tegema iga märksõnaga eraldi otsingu ning saadud tulemusi omavahel võrdlema. Seda me ei teinud, sest teemakohastest publikatsioonidest üldise ülevaate saamine tundus olulisem kui terminoloogiliste finesside tundmaõppimine. Samuti tekkis küsimus, kuidas käsitleda (s.t hõlmata) teiste distsipliinide (nt ajaloo, võõrfiloloogia) raames kirjutatud kirjandusteaduslikke või -loolisi uurimusi? Kuidas saada kätte need, mis on sootuks interdistsiplinaarsed? Head vastust sellele küsimusele me ei leidnud. Ülesanne jääb ilmselt püsti järgmiste aastate ülevaadete tegijate jaoks.

Et nii ESTER-i kui ka ISE liitotsingu väljad on piiratud tähemärkide arvuga ning otsinguvälju on kolm, siis ei ole võimalik päringusse lisada lõpmatut arvu täpsustavaid märksõnu. Subjektiivse otsustuse põhjal valisime kahele väljale need, mis meie ülesandepüstituse juures tundusid kõige hädavajalikumad, ning pühendasime ühe otsinguparameetrite välja ka nendele kirjetele, mida me oma valimis näha ei soovinud. Etteruttavalt tuleb ütelda, et sõel ei saanud siiski viimseni tihe, sest mõned olulised artiklid jäid sel viisil leidmata ja kummalisel kombel suutsid mitmed välistatud tunnustega varustatud tekstid end ikkagi valimisse sokutada. Päringu struktuur ${ }^{8}$ sai järgmine: [d:(d:kirjandusteadus or d:kirjandusajalugu or d:kirjanduskriitika) or $\mathrm{d}$ :(d:kirjandussemiootika or d:kirjandusteooria or d:võrdlev kirjandusteadus) and not d:(d:tõlked and not d:bakalaureusetööd and not d:magistritööd)]. Lisaks rakendasime ajavahemikupiirangut (ilmumisaastad pärast 2009 ja enne 2013). Sarnase struktuuriga otsingud tegime ka keelte kaupa: võõrkeelte puhul lisati liitotsingu päringusse sõnaväli „eesti”; vene keele puhul seadsime piiranguks ilmumiskohana Tartu või Tallinna.

Meie otsingute ülesehituse juures tekitas küsimusi veel põhimõtteline segadus selles osas, kas märksõnastatakse kirjutist või kirjutise objekti. Näiteks võiks olla kirjandusteadlase Toomas Liivi möödunud aastal välja antud arvustuste, esseede ja artiklite kogumik „Tekst teeb oma töö” (Eesti Keele Sihtasutus, 2012), mis koondab töid pikast perioodist 1976-2009. Sellega, et Toomas Liivi tekstide näol on tegemist kirjandusteadusega, on nõus ka ESTER. Ent

\footnotetext{
${ }^{7}$ ems.elnet.ee

${ }^{8}$ Päring on vormistatud ESTER-i märgendust kasutades, kus d: tähistab märksõnavälja ning „or” ja „and not” on vastavalt loogikaoperaatorid „või” ja „aga mitte”.
} 
kui sestsamast raamatust kirjutatakse Sirpi arvustus, kas ka selle märksõnaks sobib tingimata kirjandusteadus, kui see on publikatsioonide kirjeldamisel üldiselt kitsilt jagatud hinnang, või oleks valikus loogilisem vaid kirjanduskriitika/raamatuarvustused/raamatututvustused? Või teisalt, kui Liina Lukase aasta parima artikli auhinnaga pärjatud kirjanduslooline uurimus 1.1 kategooria ajakirjas on saanud märksõnadeks eesti, rahvaluule, baltisaksa ja luule, siis jääb ta kirjandusteaduse mõistepesa kaudu otsides lihtsalt tulemuste seast välja.

Kuna meie eesmärgiks oli siiski võimalikult katva ülevaate saamine, püüdsime selliseid lünki vältida meie peamiste kodumaiste 1.2 ja 1.3 kategooria humanitaarajakirjade sisukordades käsitsi ,järelnoppimist” rakendades. Ülevaade ei ole aga kindlasti ammendav: raske oli niiviisi leida näiteks väljaspool Eestit ilmunud konverentsikogumikke, eriti interdistsiplinaarseid. Samuti ei kajastu ISE-s kõigi kodumaiste avatud juurdepääsuga (open access) ajakirjade ${ }^{9}$ sisu (nt Studia Humaniora Tartuensia sisu on avatud ainult aastate 2000-2005 kohta). Neid kontrollisime oma raamatukogu-professionaalidest nõuandjate osundusel pisteliselt samuti käsitsi, kuid täielikku ülevaadet ei ole siingi võimalik garanteerida.

Veel üks allikas, kust vähemasti teoreetiliselt võiks saada kõige ajakohasema ja värskema info Eesti teadusasutustega seotud uurijate tegevuse kohta, on Eesti Teadusinfosüsteem ETIS, mis „koondab informatsiooni teadus- ja arendusasutuste, teadlaste, teadusprojektide ning erinevate teadustegevuse tulemuste kohta". ${ }^{10}$ Kahjuks puudub selles võimalus otsida publikatsioone üle kogu ETIS-e - tingimus, mis võiks aidata realiseerida selle kena kohakese potentsiaali olla kasutatav Eesti teadusinfo portaalina. Praegu on küll võimalus publikatsioonijahi eesmärgil uurida läbi meile teada olevalt kirjandusteaduse või sellega sarnaste ainevaldkondadega tegelevate inimeste kontosid ühekaupa. Nii saadavate lisanduste hulgaga võrreldes oleks säärane töö olnud liiga ajakulukas - ja taas mitte ammendav: mitte kõik kasutajad ei värskenda jooksvalt oma kontosid. Paljud olulised uurijad, kellel puudub selleks institutsionaalne surve (või väljund), oma tegevust ETIS-es ei kajastagi.

Niisiis tuleb tõdeda, et meie materjalikogumise metoodikas oli mitmeid objektiivseid ja subjektiivseid puudujääke. Olemasolevatest võimalustest püüdsime oma oskuste kohaselt võtta maksimumi, kuid arenguruumi on küllap veel nii otsijatel kui ka otsivahendeil.

\section{Tulemused: numbrilisi näitajaid}

Lisaks märksõnade järgi otsimisele on võimalik raamatukogunduslikes andmebaasides kasutada ka üht formaliseeritumat tunnust, UDK-d. ${ }^{11}$ Kirjandusteadust UDK alusel otsides olid saadud tulemused siiski liiga ebaühtlased, et selle pealt mingeid üldistusi teha. ISE-s saab otsida ainult [UDK: 82], mis annab väga laialt kõik kategooriasse „Kirjandusteadus. Ilukirjandus” kuulu-

${ }^{9}$ Nimekirja vt Tartu Ülikooli raamatukogu avalehelt aadressil utlib.ee lingi „Open access" alt.

${ }^{10}$ etis.ee

${ }^{11}$ Universal Decimal Classification, raamatukogude rahvusvaheline liigitussüsteem, milles kirjandus on rühmitatud teadusalade kaupa numbriliste indeksite järgi, vt udcc.org; lingi „Resources” $\rightarrow$ „UDC Summary” all leiduvad liigituse eestikeelsed vasted. 
vad artiklid (ajavahemikus 2010-2012 on selliseid Eestis registeeritud 6370 tükki); ESTER-is seevastu saab otsida nii [UDK: 82.09] („kirjandusteadus”), mis piiranguga „eesti keel” annab viis tulemust, kui ka [UDK: 82.091] („Võrdlev kirjandusteadus. Komparativistika"), mis eesti kirjandusteadusega seotud tulemusi ei andnud.

Materjali ja metoodika alapeatükis kirjeldatud struktuuriga märksõnaotsing andis ESTER-is registreeritud materjali numbrilisteks tulemusteks järgmist. Möödunud kolmel aastal on ilmunud 15 kirjandusteaduslikku monograafiat, neist üheksa doktoriväitekirjad. Keeleliselt jaotumuselt on lisaks eestikeelsetele monograafiatele ilmunud kolm venekeelset ja üks saksakeelne doktoritöö. Huvitaval kombel ei kajasta andmebaas sellest perioodist ühtki inglise keeles kirjutatud monograafiat.

Ühe autori pikema aja jooksul kirjutatud ja eri teemavaldkondadest pärinevaid artikleid koondavaid kogumikke on kolme aasta jooksul ilmunud 24 . Nende hulgas on nii meie hulgast juba lahkunud uurijate töödest postuumselt koostatud valimikke kui ka kirjandusväljal tegutsevate täies elu- ja löögijõus meeste raamatuid. Selle grupi juures torkab silma sooline tasakaalustamatus: kõigest neli nimetust on naisautoritelt, sealjuures üks neist on surnud ja teise akadeemiline karjäär on seotud USA-ga.

Teine grupp kogumikke koondab mitmete eri autorite kirjutatud artikleid. Oma koostamisprintsiipidelt on need üpris erinevad: konverentsikogumikud, grandikogumikud, ühe autori või teema vaatlused, juubelipuhused pühendusteosed, ülikoolide kogumikud parimaist üliõpilastöödest. Selliseid segakogumikke on meie andmetel kolme aasta jooksul avaldatud kokku 21. Sageli on nende institutsionaalset „kuuluvust” raske tuvastada, sest väljaanded ning neis avaldatud üksikartiklid on seotud väga erinevate sihtfinantseeritavate teemade, grantide ja projektidega. Omast kohast on see väga positiivne, sest näitab, et loovat ja viljakat uurimistegevust ei ole võimalik jaotada ühesuurusteks institutsionaalseteks kastideks; administratiivsed piirid on koostöö eri vormide korral enamal või vähemal määral hägused või kaotavad oma tähtsuse hoopis. Samal ajal tuleb tõdeda, et rõommu loovast koostööst ei pärga tavaliselt tunnustus teadusklassifikaatorite näol: enamik neist väljaannetest liigitub ETIS-es kategooriasse 3.2, mis on küll tugev keskmine, kuid näiteks doktoritöösse sellises kohas avaldatud publikatsioonil asja ei ole. Lisaks võime oma isikliku osaluskogemuse põhjal kinnitada, et kogumike koostamine, toimetamine ja avaldamine on väga energia- ning ressursimahukas tegevus. Enamasti võetakse need lugejate poolt tänuga vastu, paljudel neist on suur potentsiaal saada kasutatud kõrgkoolide õppekirjandusena, kuid mingilgi määral „teaduseks” klassifitseeruvad need ainult juhul, kui nad on avaldatud mõnes väljaspool Eesti Vabariiki asuvas kirjastuses (teadusbürokraatlikult korrektses sõnastuses: „rahvusvaheliselt tunnustatud teaduskirjastuses”). ${ }^{12}$

Otseselt gümnaasiumidele suunatud kirjanduse teemalisest õppekirjandusest (töövihikuid arvesse võtmata) on ESTER-is kajastuvate andmete kohaselt ilmunud üks õpik, kaks mõistelist sõnastikku ning üks positivistliku kallakuga ülevaade, kokku neli raamatut. Siinjuures on veel oluline mainida kirjanduslooliste allikmaterjalide publikatsioone, mida tuvastasime antud perioodil kaks (üks kirjavahetus ja üks mälestusteraamat).

${ }^{12}$ Loendiga saab tutvuda aadressil etag.ee/teaduskirjastused. 
Kohaliku kirjandusteaduse arengu seisukohalt olulisi teoreetilisi tõlketeoseid andis otsing viis. Nende kohta tuleb sedastada sama mis kogumike puhul - tõlketegevus ei ole meil väärtustatud teadustegevusena, kuna selle staatus on ETIS-es madalaim võimalikest: 6.7 ehk „muu loome”. Nagu me aga artikli sissejuhatavas osas tõdesime, ei ela Eesti kirjandusteadus kaugeltki vaakumis ning kõrgel tasemel teooriavahenduse bürokraatlike vahenditega olematuks pisendamine ei teeni kindlasti meie maailmateadusega lõimumise huve.

Jätkväljaannete (s.t aperioodiliselt ilmuvate kogumike) kategoorias jätkab vapralt Kirjandusmuuseumi aastaraamat, kuid analoogsete publikatsioonide vähesus (et mitte öelda olematus) viitab, et tegemist võib olla anakronismiga. Tänapäeva teaduspoliitika soosib ajakirju. Neid ilmub meil rõõmustavalt palju. Kirjandusteaduslikud artiklid on enamikus ilmunud ajakirjades Keel ja Kirjandus, Vikerkaar, Akadeemia, Looming, aga ka Tuna ja Trames. Eksklusiivsemalt kirjandusküsimustele pühendatud väljaannetest on ilmunud neli Tartu Ülikooli kultuuriteaduste ja kunstide instituudi ning Eesti Kirjandusmuuseumi kultuuriloolise arhiivi ühisajakirja „Methis. Studia humaniora Estonica" numbrit: omaelulookirjutuse erinumber (nr 5/6) 2010. aastal, nõukogude aja erinumber (nr 7) ja vabanumber (nr 8) 2011. aastal ning tõlkeloo erinumber (9/10) 2012. aastal. Interlitterariaid, Tartu Ülikooli maailmakirjanduse õppetooli ja Eesti Võrdleva Kirjandusteaduse Assotsiatsiooni rahvusvahelisi aastakirju, mis viivad kokku maailmakirjanduse ja rahvuskirjandused ning peegeldavad neid inglise, prantsuse, saksa ja hispaania keeles, mahub vaadeldavasse perioodi kolm, numbrid 15-17.

Artiklitena vormistatud uurimuste hulk vaadeldaval ajavahemikul - eriti raamatute hulgaga võrreldes - on muljetavaldav. Arvuliselt raskem on hinnata arvustuste, ülevaadete ja muude „metatekstide”, ees- ja saatesõnade, kommentaaride jms arvu, kuna see nõuaks taas võrdlevaid otsinguid iga märksõnaga eraldi. Sestap on järgnevad tulemused ${ }^{13}$ antud ainult artiklitena klassifitseeritud kirjete alusel. Meie otsingu tulemusel on kirjandusteaduslikke (või mõne muu seotud märksõnaga märgendatud - vt loendit „Materjali ja metoodika” alapeatükist) tekste vaadeldava kolme aasta jooksul ilmunud ajalehtedes 30 , ajakirjades 133 ning kogumikes 369, kokku 532. On võimalik, et eri otsingutega leitud tulemuste puhul mõned kirjed kattuvad (nt kui artikkel on esmalt ilmunud ajakirjas ning seejärel taasavaldatud konverentsikogumikus), või mõned kirjed on puudu (nt kui artikkel on ilmunud mõnes väljaandes, mida ISE-s ei kataloogita). Statistilise vea piiresse jäädes võib humanitaarse umbmäärasusega siiski öelda, et kirjanduse uurimisele on kolme aasta jooksul pühendatud circa pool tuhat eesti kultuuri jaoks olulistes avaldamiskanalites ilmunud artiklit. Tahaks öelda - seda ei olegi nii vähe. Kuid hinnangu andmine kuulub teadusartikli ülesehitusloogikas järgmise alapeatüki ülesannete hulka.

\section{Arutelu: sisulisi sissevaateid}

Järgnevas esitame tähelepanekuid numbriliste näitajate taga seisvate publikatsioonide sisulise külje kohta. Arvestades materjali hulka - kokku 70 tervikteost ja 532 artiklit - ei ole siinne ülevaade täielik ses mõttes, et mitte iga

${ }^{13}$ Numbrid kajastavad ainult uurimuslike artiklite hulka; raamatuarvustusi, intervjuusid jms metakirjanduslikke tekste ei ole selles kogumis hõlmatud. 
kirje taga seisva publikatsiooni kohta ei võtnud me eesmärgiks välja kujundada oma kvalitatiivset seisukohta. Taas kord seavad ülevaate maht ja selle koostamiseks meie kasutada olnud aja- ning jõuvarud omad piirid. Esitame sissevaated avaldatu sisusse samas järjekorras, nagu käsitlesime numbrilisi tulemusi: esmalt monograafiad ja kogumikud, seejärel artiklid.

Üldise teaduspoliitilise tähelepanekuna võib märkida, et monograafiaid ja ühe-autori-kogumikke avaldavad valdavalt need, kes on vaba(ma)d institutsionaalsetest klassifikaatoripainetest: loovisikud, välismaalased, surnud autorid ja paar boheemlaslikumat professorit.

Tekstide lähem vaatlus näitab, et ühtpidi ei unustata eesti kirjandusteaduses eesti klassikuid, teisalt on sageli tegemist väga huvitavate uute uurimissuundade ja teemadega, mida rikastab omakorda just interdistsiplinaarsus. Ei puudu klassikaline kirjandusuurimus ja teemad, mis on n-ö igipõliselt huvitavad, ega ka kirjandusloolised süvauurimused. Kirjandusloolise lähenemise üheks ehedamaks näiteks on möödunud aastal ilmunud Livia Viitoli monograafia „Eduard Vilde” (Viitol 2012). Märkigem veel saatetekstiga varustatud taastrükki Valev Uibopuu ülevaatest „Välismaine Eesti Kirjanike Liit” (Uibopuu 2012), Ilmamaa „Eesti mõtteloo” sarjas 2011. aastal välja antud Rudolf Põldmäe „Vennastekoguduse kirjandust” (Põldmäe 2011) ja Leili Iheri monograafiat „Gustav Suitsu jälil: fakte ja mõtisklusi” (Iher 2011). Jüri Talveti „Juhan Liivi luule" (Talvet 2012) sisaldab uut, selgitab vana ja ärgitab seejuures uute küsimuste/vaatenurkade kallale asuma, irriteerides siinkohal juba võrdlusmaterjaliga: aluseks on ikkagi Juhan Liiv kui maailmakirjanik. Kui veel armastatud klassikuist rääkida, on oluline ka ära märkida, et Sirje Kiini 2009. aastal juba ilmunud doktoritööst, Marie Underi käsitlusest, on avaldatud kordustrükk pealkirjaga „Marie Under. Elu ja luule” (Kiin 2011). Siinsamas on aga näide lähemast poolsajandist: Kersti ja Marja Unt on pealkirja all „Seilates sadamata" (Unt, Unt 2012) koostanud ülevaate almanahhiliikumisest ja omakirjastusest okupeeritud Eestis. Näib, et Eesti kirjandusklassikuid käsitlevate tekstide ilmumiseks on vajadus - iseasi, kas on jõudlust ja võimalust (loe: toetussüsteeme) neid välja anda. Monograafiate toimetamisele paistavad olevat spetsialiseerunud Brita Melts (Underi, Suitsu ja Vilde monograafiad) ning Janika Kronberg (Vilde ja Under; Uibopuu raamatu järelsõna).

Maarja Vaino doktoriväitekiri (2011) kõneleb irratsionaalsuse poeetikast A. H. Tammsaare loomingus, Mirjam Hinrikuse dissertatsioon (2011) dekadentlikust modernsuskogemusest A. H. Tammsaare ja nooreestlaste loomingus. Ave Mattheus (2012; kaitses kraadi 2013) on ajas läinud veel kaugemale: uuritud on eesti laste- ja noortekirjanduse tekkelugu üldse, Katre Kaju väitekiri (2011) on vaadelnud Riia vaimuliku Adam Andreae reisialbumit (16961702).

Kirjandusteoreetilist vaatepunkti esindab Jaak Tombergi väitekirja põhjal valminud monograafia „Kirjanduse lepitav otstarve” (2011, kaitstud 2009) kirjandusfilosoofiast, fiktsiooniteooriast, võimalikkusest ja tegelikkusest. Tombergi haare on avar, ent võrdluseks saab nentida, et meie kirjandusteadlaste teemadering ongi lai: näiteks Tallinna Ülikooli Kirjastuse välja antud Olesja Lagašina 2009. aastal kaitstud väitekiri Lev Tolstoi ideede retseptsioonist vene eksiilkirjaniku Mark Aldanovi loomingus (Lagašina 2010) või samalt kirjastuselt ka kirjandus- ja keeleteadlaste Suren Zoljani ja Mihhail Lotmani artiklikogumik vene akmeismi semantilisest poeetikast (Zoljan, Lotman 2012), 
mis on pühendatud Ossip Mandelštami ja Anna Ahmatova poeetikale. Inna Bulkina (2010) on vaadelnud XIX sajandi vene ilukirjanduses loodud Kiievit, Aleksei Vdovin (2011) „kirjanduse liidri” kontseptsiooni 1830.-1860. aastate vene kirjanduskriitikas. Eestit ja kirjandust puudutavaid väitekirju on ilmunud ka mujal: Saksamaal on avaldatud Reet Liimetsa raamat „mina” konstrueerimisest võrdlevalt eesti ja saksa noorte elufiktsioonides (Liimets 2011) ja Ulrike Plathi doktoritöö „Esten und Deutsche in den baltischen Provinzen Russlands: Fremdheitskonstruktionen, Lebenswelten, Kolonialphantasien 1750-1850" (Plath 2011), mis analüüsib muuhulgas maastiku kujutamist reisikirjades ning kultuuriliste nähtuste diskursiivset konstrueerimist Baltikumi kontekstis ja mujal. Väga oluline on ka kogumiku „Humanitaarteaduste metodoloogia” (Tamm, Marek 2011) ilmumine Tallinna Ülikooli kirjastuselt (ehkki „kirjandusteaduse” märksõnaga otsides seda ESTER-ist ei leia).

Kaaluka panuse kirjandusteadusse on andnud eespool mainitud mahukad ühe-autori-artiklikogumikud August Annisti (2011), August Eelmäe (2012), Jüri Haini (2011), Toomas Haugi (2010), Ivar Ivaski (2010), Jan Kausi (2012), Mihkel Kunnuse (2012), Marju Lepajõe (2012), Toomas Liivi (2012), Arne Merilai (2011a, 2011b), Ilmar Mikiveri (2010), Ott Ojamaa (2010), Hugo Raudsepa (2012), Paul-Eerik Rummo (2010), Joel Sanga (2010), Malle Salupere (2012), Marta Sillaotsa (2012), Vaapo Vaheri (2012), Rein Veidemanni (2010) ja Tõnu Õnnepalu (2011) töödest. Neistki mõni lähtub intrigeerivalt muudest valdkondadest kui otseselt kirjandusest: näiteks kunstiteadlane Jüri Hain kirjutab oma „Raamatulehitsejas” kirjandusest raamatuillustratsiooni kaudu.

Niisama olulised on tõlke kaudu eesti keelde jõudnud väljaanded, nagu Maire Jaanuse artiklikogumik „Kirg ja kirjandus” (2011; tõlkinud Krista Kaer, Anne Lange, Kristin Sarv, Ene-Reet Soovik, Kajar Pruul ja Märt Väljataga). Tõlgitakse ja avaldatakse muudki huvitavat ja olulist: Kalle Kasemaa on tõlkinud Erich Auerbachi „Mimesise” (2012), Heete Sahkai Paul Bourget' „Esseid kaasaja psühholoogiast" (2011), Urmas Tõnisson, Ene-Reet Soovik ja Katre Ligi René Welleki ja Austin Warreni „Kirjandusteooria” (2010), Kaia Sisask Leonidas Donskise (2010) teose „Armastus, vihkamine ja vastuseis”. Siinkohal on sobiv ära märkida ka edenemine tõlkeloo, tõlketeooria ja tõlkimise uurimise alal, mille eestvedajaiks on suuresti TLÜ germaani-romaani filoloogid ning TÜ semiootikud. Üheks näiteks viljakast institutsioonidevahelisest koostööst on tõlke-Methis.

Teine intrigeeriv ja rakenduslikult mõttekas kogumike koostamise printsiip, ühe-autori-uurimused, on vaadeldaval perioodil toonud koondvaatluse näiteks „Sügisballist” (Sarapik, Viires 2010), Mehis Heinsaarest (Vabar 2011), Andres Ehinist (Merilai 2012), Uku Masingust (Merilai 2010), aga ka Sergei Dovlatovist (Popov 2011), Paul Flemingist (Tarvas 2011), Aino Kallasest (Kurvet-Käosaar, Rojola 2011), Aleksandr Puškinist ja tema ajastust (viimane Larissa Volperti juubeliga seoses; Leibov 2011). Juubelipuhuste pühenduskogumikena on ilmunud kirjandus-, tõlke- ja kultuurilugu üldisemaltki käsitlevad kogumikud Ljubov Kisseljova (Leibov 2010), Peeter Toropi (Kroó, Avramets 2010) ja Sergei Issakovi (Kisseljova, Stepaništševa 2011) tähtpäevadega seoses. Siiakanti sobitub ka almanahh ajakirjas Vikerkaar ilmunud valitud kirjutistest (Niit, Klement 2010). Tallinna Ülikool on 2011. aastal välja andnud veel kogumikud „Noored filoloogid” (Mattheus, Zabrodskaja 2011), „Uurimusi 1940. aastate eesti kirjandusest” (Kõvamees, Viires 2011) ja „Kõnetav kultuur” 
(Veidemann, Kepp 2011). Tartu Ülikooli kirjastusel on ilmunud klassikalise filoloogia (Päll jt 2010), narratoloogia (Grišakova 2010) ning vene-eesti kirjandussuhete (Pild 2010) teemalised artiklikogumikud. Kirjanduslooga seotud uurimusi sisaldab ka Ajalooarhiivi välja antud artiklikogumik (Põltsam-Jürjo, Tannberg 2011). Pariisis on ilmunud eesti ja soome ulmekirjanduse teemaline kogumik (Carayol 2012) ja Jaan Krossile pühendatud konverentsikogumik (Carayol 2011), Vilniuses Baltimaade nõukogudeaegset kirjandust käsitlev kogumik (Baliutytè, Mitaitè 2011), Berliinis Baltimaade saksakeelset kirjandust käsitlev kogumik (Bosse jt 2011) ja Baltimaade kirjandusloo alane teos (Gottzmann 2010), Münsteris neljaosaline reformatsiooniaegset kultuurilugu käsitlev kogumik (Asche jt 2009-2012), Frankfurdis tõlkelooalane konverentsikogumik (Chalvin jt 2011), mis kõik sisaldavad ka eesti kirjandust puudutavaid uurimusi.

Kirjandusloo allikaist on avaldatud kommenteeritud kirjavahetusi (Artur Adson - Friedebert Tuglas ehk „Paaži ja Felixi kirjavahetus 1917-1944”; Eelmäe 2011) ja usutlusi [Jaak Urmeti vestlused Ralf Parvega „Minu aeg: kirjandusloolised vestlused” (Parve 2010) ja Enn Vetemaaga „Mees nagu saksofon” (Vetemaa 2012)] ning kogutud teoseid (Friedrich Robert Faehlmanni kogutud teoste III osa, Eesti Kirjandusmuuseumi ja Underi ja Tuglase Kirjanduskeskuse ühisväljaanne; Metste jt 2011).

Interdistsiplinaarsuse heaks näiteks on Underi ja Tuglase kirjanduskeskuse väljaanne $\mathrm{nr} 24$ sarjas Collegium litterarum, „Umweltphilosophie und Landschaftsdenken im baltischen Kulturraum. / Environmental Philosophy and Landscape Thinking" (Lukas jt 2011), mille teemapüstituseks on ühise loodusliku keskkonna mõju Baltimaade kultuuridele ja sellest tõukuv võimalik rahvusülesus.

Artikliotsinguga leidsime veel trobikonna eesti uurijate üksikartikleid sellistes rahvusvahelistes konverentsikogumikes nagu "Glanz und Elend" (Mühlen 2012), „Formal methods in poetics” (Scherr 2011), „Маргиналното в/ на дитературата" (Kuntševa 2011). (Lähemalt saab artiklikirjetega tutvuda ajakirja Keel ja Kirjandus uuenenud kodulehel. ${ }^{14}$ ) Üksikkäsitlustel lähemalt peatumata võib tõdeda, et eesti humanitaarteadlased on täiesti suutelised osalema rahvusvahelises kirjandusteaduslikus diskussioonis.

Kõige raskem ülesanne on anda ülevaade neist poolest tuhandest (või enamast) artiklist, mis meie otsingu tulemusena „kirjandusteaduseks” osutusid. Teeme seda avaldamiskohti alfabeetilises järjestuses ära märkides, tuues välja ka üldisi tendentse ja huvitavamaid erandeid. Paljude ajakirjade puhul on sisukorrad (mitmetel ka täistekstid) võrgus kättesaadavaks tehtud. Kui ajakirjal on olemas sisule avatud juurdepääsu pakkuv võrgukoht, oleme selle ära märkinud. Kõigi otsingu tulemusel andmebaasist ISE leitud kirjete tabeliga saab samuti tutvuda Keele ja Kirjanduse kodulehel. Ajakirjades ilmunud kõigist artiklitest mis tahes ajavahemikul saab hõlpsasti ülevaate ka ISE kaudu, kui liitotsingus määrata väljaande pealkiri ja soovitud ajavahemik. Sellisel moel järelkontrolli tehes täienes meie artiklikirjete hulk mitme olulise publikatsiooni võrra, millel „kirjandusteaduse” mõistepesaga seotud märksõnad puudusid, kuid sisuline seos sellega (nt Karl Ristikivi loomingu analüüs) oli ilmselgelt olemas.

\footnotetext{
${ }^{14}$ kjak.eki.ee
} 
Acta Semiotica Estica ${ }^{15}$ koondab eestikeelseid semiootilisi ja kultuurianalüütilisi uurimusi. Kirjandusteaduse seisukohast olulisi artikleid võib selle sisukorrast välja noppida pigem kümmekond kui see üks, mida pakub ISE (kollektiivse autori mõistest; Tamm, Margus 2011). Artiklid on valdavalt interdistsiplinaarsed (mis samuti raskendab nende märksõnastamist), analüüsides kirjandustekstide siirdeid nii teistesse keeltesse, teistesse meediumidesse kui ka nende kasutamist ideoloogia tööriistana.

Tartu Ülikooli ajaloo ja arheoloogia instituudi väljaandel ilmuv Ajalooline Ajakiri on avaldanud huvitava kirjandusloo taustu avava käsitluse Eesti kirjanike loomingulistest komandeeringutest stalinismi ajal (Mandel 2011).

Akadeemia paistab silma kirjanduslooliste käsitluste ja ilmunud monograafiliste uurimuste arvustuste avaldamisega. Samuti on tänu Akadeemiale võimalik eesti keeles lugeda siinsete maailmatasemel sumeroloogide uurimusi (Sazonov 2010). Vanima kirjanduse alaseid ning Uku Masingu pärandit puudutavaid kirjutisi leidub ka Usuteaduslikus Ajakirjas. ${ }^{16}$

Teadusandmebaasides indekseeritud Journal of Baltic Studies (muuhulgas saab jälgida ka artiklite tsiteeritavust!) on lisaks juba eespool mainitud Liina Lukase artiklile baltisaksa kirjanduse allikatest (Lukas 2011) avaldanud tõlketeoreetilise artikli Anne Langelt (2012) ning geopoliitilise suunitlusega, nõukogude aega kolonialismi terminites uuriva käsitluse kirjandusteadlaselt Epp Annuselt (2012).

Interlitteraria kolmes numbris ilmunud 83 artiklist on kirjandusteaduse või selle hõimlastena ISE-s märgendatud kümme. Seda on esinduslikuks valimiks ilmselgelt liiga vähe. Eesti teadlastelt on kolme aasta jooksul selles ajakirjas avaldatud kokku 37 artiklit. Uurijad tegelevad enamasti oma ootuspäraste põhiteemadega: maailmakirjandus, värsiõpetus, linnakirjandus, Briti kirjandus, dekadents, kirjandusloo soolistatus, tuumstruktuurid, omaelulookirjutus, kirjanduslugu digitaalkeskkonnas, tõlkelugu... Interlitteraria numbrite kohta on ilmunud mitmeid tutvustavaid metakirjutisi (nt Pilter 2011; Melts 2012). Ajakirja sisuga soovitame tutvuda avatud juurdepääsuga CEEOL-i platvormil, ${ }^{17}$ kus on kättesaadavad kõigi artiklite täistekstid.

Keelt ja Kirjandust võib pidada eesti kirjandusteaduse põhiliseks kodumaiseks avaldamiskohaks (erinevalt Akadeemiast, Loomingust ja Vikerkaarest on tema klassifikaator 1.2, mitte 1.3) ning siin ilmuvad olulisemad kodumaised kirjandusteaduslikud publikatsioonid. ISE andmeil on neid kokku 24 (jättes otsingutulemustest välja kõik arvustused ja konverentsiülevaated, mida tuli teist sama palju). Diferentseeritum otsing ainult Keele ja Kirjanduse artiklite seast jättis meie jaoks kirjandusteadusena, sh kirjandusloona sõelale poole rohkem artikleid. Mitmed neist on mujal inglise keeles avaldatud artiklite eestikeelsed versioonid, millest võiksime teha järelduse, et ainult võõrkeelsete artiklite avaldamine ei ole meie uurijatele vastuvõetav. Asjatundliku auditooriumini jõuavad kohalikus, suhteliselt laialdase levikuga ajakirjas avaldatud käsitlused märksa hõlpsamini kui mõnesse institutsionaliseeritud juurdepääsuga tähtsasse andmebaasi talletatud kõrge impact factor'iga teaduspublikatsioonid. Kui uurimistöö tegemise eesmärgiks on teadmuse levik, tasub tule-

\footnotetext{
${ }^{15}$ Artiklite lühikokkuvõtteid sisaldav võrguleht asub aadressil semiootika.ee/acta

${ }^{16}$ Täistekstid aadressil usuteadus.ee

${ }^{17}$ ceeol.com; väljaandeid saab vaadata maade kaupa. Eesti ajakirju on loetelus 21, enamik neist humanitaarse suunitlusega.
} 
musi avaldada emakeelseis väljaandeis. Keele ja Kirjanduse täistekste saab lugeda nii DIGAR-i, CEEOL-i kui ka ajakirja kodulehe vahendusel.

Teine suur vaal eesti kirjanduse mõtestamisega tegelejate jalge all on Looming, kus avaldavad uurimuslikke tekste pigem need autorid, kelle suhtes klassifikaatorisurve on nõrgem või toimib mõnes teises valdkonnas. Iseloomulik on ka see, et luule ja proosa aastaülevaadete põhiline avaldamiskoht tundub praegusel ajal olema just Looming (mis ongi selleks otstarbeks väga õige koht). Looming toimib ka eesti kirjanduse sillalauana maailmakirjandusse, kuivõrd avaldab regulaarselt maailmakirjanduse tähelepanuväärsete sündmuste ja isikute ülevaateid. Kirjanduse ülevaadetega kokku (ja arvustusi välja jättes) on ISE kohaselt kolmel aastal Loomingus ilmunud 17 kirjandusteaduslikku artiklit. Käsitsi (ja ilmselt natuke loomingulisemalt) noppides tuli selliseid 48. Sellesse hulka on arvatud ka ulatuslik mõttevahetus nullindate kirjanduse üle. Loomingus ilmunule on raske mõnd ühist nimetajat leida; huvilised saavad asjakohaste loenditega tutvuda ka ajakirja kodulehel ${ }^{18}$ (kõigi artiklite täistekste seal siiski väljas ei ole). Loominguline kirjusus teeb sellest ajakirjast sümpaatse avaldamiskoha.

Sirbist valib otsing välja 30 artiklit, niisiis keskeltläbi kümmekond iga aasta kohta. Regulaarselt ilmuvate kirjanduskülgedega väljaande kohta on seda vähevõitu, kuid ka statistilise aluseta empiirilise tähelepaneku alusel tundub, et muud kunstiliigid kipuvad seal sageli lehekülgede hulga poolest kirjandusalaste refleksioonide üle domineerima.

Eesti Teaduste Akadeemia humanitaarteaduslik kvartalikiri Trames (samuti klassifikaatoriga 1.2) on avaldanud igal aastal ühe kirjandusteadusega servapidi piirneva artikli (Undusk 2012; Põldvee 2011; Torop, Osimo 2010).

Rahvusarhiivi kureeritavas ajalookultuuri ajakirjas Tuna ilmub kirjanduslooline rubriik „Kultuuriloolisest arhiivist”, kus avaldatakse koos kommentaaridega huvitavaid leide Eesti Kirjandusmuuseumi Kultuuriloolisest Arhiivist - taaskord üks hea näide asutustevahelisest sujuvast koostööst. Arhiivileiu rubriik on ka ajakirjas Methis.

Vikerkaares, mis on kahtlemata meie kodumaise kirjandusteadusliku mõtte kolmas vaal, jätkuvad mõned „põlised traditsioonid” - Tiit Hennoste „hüpped” on heaks näiteks. Artiklite üldine suunitlus on pisut teooriakesksem kui Loomingus, kuid vormilt vast pisut vabam kui Keeles ja Kirjanduses. Vikerkaar on ka väljaanne, mis tänuväärselt sageli avaldab oluliste kirjandusteoreetiliste tekstide tõlkeid eesti keelde (peamiselt vene ja inglise keelest). Kuna ISE otsing andis tulemuseks taas kord valdavalt kirjandusteaduslike raamatute arvustused (märksõnaga kirjeldatakse niisiis mitte arvustust ennast, vaid selle objektiks oleva teose sisu), kordasime otsingut käsitsi ja lugesime kokku täpselt 50 kirjandusteaduslikku artiklit kolme aasta kohta. Vikerkaare sisu valguskaabli vahendusel täies ulatuses nautida ei saa; kodulehel ${ }^{19}$ on üleval sisukord ja valitud artiklid.

Kirjandust mõtestavaid artikleid on vaatlusalusel kolmaastakul muuhulgas avaldanud ka väljaanded Lugu, Metsamees, Mulkide almanak, Tartu Ülikooli Lõuna-Eesti keele- ja kultuuriuuringute keskuse aastaraamat, Õpetatud Eesti Seltsi aastaraamat, Võro Instituudi toimõndusõq, Вышгород, Труды Русского исследовательского центра в Эстонии. Täpsemaid viiteid on võimalik näha tabelist Keele ja Kirjanduse võrgulehel.

\footnotetext{
${ }^{18}$ looming.ee

${ }^{19}$ vikerkaar.ee
} 
Paari sõnaga peatugem ka kirjandusteaduse metatekstidel. Loomingus ning Keeles ja Kirjanduses avaldatud ülevaadete põhjal kujuneb pilt sellest, kui palju toimub konverentse, millele need on pühendatud, ja - pikema ülevaate korral - pakutakse ka üürikest sissevaadet teemapüstitusse. Niisamuti lühiarvustatakse kaitstud üliõpilastöid. Üsna selge pildi saab sellest, kui intensiivne on arvustamine: olulise monograafia või kogumiku ilmumist saadab mitu arvustust - doktoritööde puhul on nendeks enamasti kaitsmisel esitatud oponeeringud -, mis omakorda kujunevad kindlat laadi täiendtekstideks. Teinekord on üllatus ootamatult tore, andes näiteks teadmise, et eesti kirjanduselus löövad kaasa ka isikud, kellest seda tingimata ei arvaks. Nii on teenekas ornitoloog Olav Renno (2011) tutvustanud ajalehes Sakala Rein Veidemanni raamatut „101 Eesti kirjandusteost” (Veidemann 2011), küll tunnistades, et lehelugu on tellimustöö. Seda on aga tehtud süvenenult ja värskelt vanema põlvkonna lugeja vaatepunktist. Konkurentsitult kõige populaarsem teos retseptsiooni hulga järgi arvestades ongi vaatlusalusel perioodil olnud Rein Veidemanni „101 Eesti kirjandusteost”. Tegu on nn rahvaraamatuga, mitte akadeemilise uurimusega ranges mõttes ning sestap on Veidemann kirjandusloo populariseerijana „suveräänne liider”, kui kasutada spordiajakirjanike kõnepruuki.

Üldiselt tundub, et vastukaja saadab just monograafiaid ja kogumikke; artiklite kohta on tagasisidet saada väga vähetõenäoline. Vaatamata artiklite suurele hulgale peaks see vahest panema küsima (mitte ainult uurijaid endid, aga ka teaduspoliitika kujundajaid): kas humanitaarteadustes on rahvusvahelises ajakirjas avaldatava üksikartikli vormis kommunikatsioon kõige tõhusam viis teadusliku diskussiooni üleval hoidmiseks? Kui reaalteadlased saavad kiire tagasiside oma tööle artiklite viidatavuse alusel (kusjuures palju viiteid saavad ka artiklid, milles esitatud tulemustega teised uurijad ei nõustu), siis humanitaarias pelgast viitamisest ei piisa, kui taotluseks on sisuline arutelu. Sünergia ja poleemika tekivad iseäranis huvitaval moel artiklikogumikes, olgu need siis sündinud konverentsi või grandi tulemusena või mõnel muul põhjusel.

\section{Kokkuvõte}

Nagu nägime, on eesti kirjandusteadus XXI sajandi esimese kümnendi lõpul elav, interdistsiplinaarne ja rahvusvahelise haardega vaimutöö valdkond. Ilmunud uurimusi on vormistatud nii raamatute kui ka artiklite kujul, viimaseid umbes seitse korda rohkem kui esimesi. Elavam vastukaja on saatnud monograafiaid ja kogumikke. Artiklid teenivad mõnigi kord avaldamiskohtade klassifikaatorite sinilinnukeste püüdmise eesmärki, kuid teaduslikku poleemikat ei tekita. Kindlasti ei tohi väita, et (indekseerimata) ajakirjades avaldatud uurimuste tase oleks madal; pigem on küsimus selles, missugused väljaanded osalevad laiemas maiskondlikus teadmusringluses ja missugused mitte.

Eestis ilmunud ja eesti kultuuri seisukohalt relevantseid väljaandeid kataloogivad järjepidevalt Eesti Raamatukoguvõrgu Konsortsiumi liikmesraamatukogud ning need avalikustatakse andmebaasides ESTER ja ISE. Samuti on mitmed väljaanded kättesaadavad Rahvusraamatukogu digiarhiivi DIGAR kaudu. Paljud ajakirjad on indekseeritud rahvusvahelistes teadusandmebaa- 
sides ning täistekstidena kättesaadavad CEEOL-i platvormil. Samuti on enamikul ajakirjadest oma koduleht, mille kaudu on - kas osaliselt või täielikult - lahendatud avatud juurdepääs väljaande sisule.

Meie tehtud tööd ja saadud järeldusi ei tohiks pidada lõplikuks tõeks, sest materjal on märksa ulatuslikum ja mitmekesisem, kui isegi kahe naisterahva teravdatud tähelepanu vastu suudab võtta. Detailideni täpse ülevaate saamiseks tuleks eelolevatel aastatel ilmselt teha järjepidevamat koostööd bibliograafidega, et katta lünki ja vältida ebajärjekindlusi uurimuste sisu määratlemisel.

Järeldus, mille kõige ülalpool kirja pandu valguses võiksime teha meie kultuuri kui terviku käekäigu kohta: üha kivinevamate formaalsete reeglite kiuste ta siiski veel liigub, loob ja lehvitab!

Käesolev artikkel on selle autorite kaudu seotud järgmiste teadusrahastuse instrumentidega: EKKM09-157 („Friedebert Tuglase, Marie Underi ja Artur Adsoni vaimne pärand”); SF0230032s08 („Autogenees ja ülekanne: Moodsa kultuuri kujunemine Eestis”); ETF7790 („Dünaamiline zoosemiootika ja loomade representatsioonid”); ETF9160 („Eesti kirjanduse pingeväljad 1956-1968: ideoloogiad, institutsioonid ja baastekstid Nõukogude ja paguluse kontekstides"); EKKM09-167 („Humanitaarajakirja METHIS rahvusvahelise taseme tõstmine”); TAP33-2 („Säilituslaborite ja-seadmete ajakohastamine"). Uuringut toetas Euroopa Liit Euroopa Regionaalarengu Fondi kaudu (Kultuuriteooria Tippkeskus). Artikli ülesehituses oleme juhindunud raamatust „How to Write and Publish a Scientific Paper” (Day, Gastel 2006; kursuse „Kuidas saada ja jääda tippteadlaseks” ametlik õppematerjal).

\section{Kirjandus}

A n n i s t, August 2011. Noorusmaa. Tartu: Ilmamaa.

A n n u s, Epp 2012. The Problem of Soviet Colonialism in the Baltics. - Journal of Baltic Studies, nr 1, lk 21-45.

A s c h e, Matthias, B u c h h o l z, Werner, S c hin d ling, Anton (toim) 2009-2012. Die baltischen Lande im Zeitalter der Reformation und Konfessionalisierung: Livland, Estland, Ösel, Ingermanland, Kurland und Lettgallen: Stadt, Land und Konfession 1500-1721. Teil 1.-4. Münster: Aschendorff.

A u e r b a c h, Erich 2012. Mimesis: tegelikkuse kujutamine õhtumaises kirjanduses. Tartu: Ilmamaa.

B a li u t y tè, Elena, M i t a i tè, Donata (toim) 2011. Baltic Memory: Processes of Modernisation in Lithuanian, Latvian and Estonian Literature of the Soviet Period. Vilnius: Lietuvių literatūros ir tautosakos institutas.

B o s s e, Heinrich, Eli a s, Otto-Heinrich, T a t e r k a, Thomas (toim) 2011. Baltische Literaturen in der Goethezeit. Würzburg: Königshausen \& Neumann.

B o u r g e t, Paul 2011. Esseid kaasaja psühholoogiast. Tallinn: Kultuurileht.

B u l k i n a 2010 = Булкина, Инна 2010. Киев в русской литературе первой трети XIX века. Пространство историческое и литературное. Tartu: Tartu Ülikooli Kirjastus.

C a r a y o 1, Martin (toim) 2011. Jaan Kross: bilan et découvertes: actes de la journée Jaan Kross, 28 novembre 2008. Paris: l'Harmattan. 
C a r a y o 1, Martin (toim) 2012. Le fantastique et la science-fiction en Finlande et en Estonie: actes du colloque, 19-20 novembre 2010. Paris: l'Harmattan.

C h a lvi n, Antoine, L a n ge, Anne, M o n t i c e lli, Daniele (toim) 2011. Between Cultures and Texts: Itineraries in Translation History = Entre les cultures et les textes: itinéraires en histoire de la traduction. Frankfurt am Main: Peter Lang.

D a y, Robert A., G a s t e l, Barbara 2006. How to Write and Publish a Scientific Paper. Westport-London: Greenwood Press.

D o n s k is, Leonidas 2010. Armastus, vihkamine ja vastuseis: uurimusi filosoofiast, poliitikast ja kirjandusest. Tallinn: Tallinna Ülikooli Kirjastus.

E el m ä e, August (koost) 2011. Paaži ja Felixi kirjavahetus 1917-1944. Tallinn: Eesti Keele Sihtasutus.

E e 1 m ä e, August 2012. Eluvõla kandmise raske kohus. Tallinn: Eesti Keele Sihtasutus.

Gottz m a n n, Carola L. (toim) 2010. Deutschsprachige Literatur im Baltikum und in Sankt Petersburg. (Literarische Landschaften 11.) Berlin: Duncker \& Humblot.

Gri š a k ov a, Marina (koost) 2010. Jutustamise teooriad ja praktikad. Tartu: Tartu Ülikooli Kirjastus.

H a i n, Jüri 2011. Raamatulehitseja. Tallinn: Arlekiin.

H a u g, Toomas 2010. Klassikute lahkumine: 25 kirjatööd. Tallinn: Eesti Keele Sihtasutus.

H e n n o s t e, Tiit 2008. Õhus on kõike. Eesti kirjandusteadus 2007. - Keel ja Kirjandus, nr 4, lk 233-250.

H i n r i k u s, Mirjam 2011. Dekadentlik modernsuskogemus A. H. Tammsaare ja nooreestlaste loomingus. Tartu: Tartu Ülikooli Kirjastus.

I h e r, Leili 2011. Gustav Suitsu jälil: fakte ja mõtisklusi. Tallinn: Varrak.

I v a s k, Ivar 2010. Hetked igavikust: meelisklusi maailma kirjanduselust. Tartu: Ilmamaa.

J a a n u s, Maire 2011. Kirg ja kirjandus. Esseid eesti ja euroopa kirjandusest ja psühhoanalüüsist. Tallinn: Vikerkaar.

$\mathrm{K} \mathrm{aj} \mathrm{u}$, Katre 2011. Vive hodie, cras vivere serum est: humanistlik-kristlik haridustraditsioon ja Riia pastori Adam Andreae reisialbum (1696-1702). Tartu: Tartu Ülikooli Kirjastus.

K a u s, Jan 2012. Elu ja kirjandus: tekste eesti kirjandusest 2004-2011. Saarde, Pärnu: Jumalikud Ilmutused.

Ki i n, Sirje 2011. Marie Under: elu ja luule. Tallinn: Tammerraamat.

Kisseljova, Ste paništš ev a 2011 = Киселева, Пюбовь, Степанищева, Татьяна (toim) 2011. Мифология культурного пространства: К 80-летию Сергея Геннадиевича Исакова. Tartu: Tartu Ülikooli Kirjastus.

Kr o ó, Katalin, Avra m ets, Irina (toim) 2010. In Honour of Peeter Torop 60: A Collection of Papers from Young Scholars. Budapest, Tartu: Eötvös Loránd University, University of Tartu.

Kunnus, Mihkel 2012. Minu eugeenika saladus: kultuurieugeenilisi koode. Saarde, Pärnu: Jumalikud Ilmutused.

K u n t š e v a 2011 = Кунчева, Рая (toim) 2011. Маргиналното в/на литературата = Marginality in/of Literature. Sofia: Боян Пенев.

Kurvet - Kä o s a a r, Leena, R ojol a, Lea (toim) 2011. Aino Kallas: Negotiations with Modernity. Helsinki: Finnish Literature Society.

Kõ v a m e e s, Anneli, Vi i r e s, Piret (koost) 2011. Uurimusi 1940. aastate eesti kirjandusest. Tallinn: Eesti Keele Sihtasutus. 
L a g a š in a 2010 = Лагашина, Олеся 2010. Марк Алданов и Лев Толстой: к проблеме рецепции. Таллинн: TLU Press.

L a $\mathrm{n}$ g e, Anne 2012. Performative translation options under the Soviet regime. Journal of Baltic Studies, nr 3, lk 401-420.

L e i b o v $2010=$ Лейбов, Роман (toim) 2010. Con amore: историко-филологический сборник в честь Любови Николаевны Киселевой. Moskva: ОГИ.

Leibov 2011 = Лейбов, Роман (toim) 2011a. Пушкинская эпоха и русский литературный канон: к 85-летию Ларисы Ильиничны Волперт. Kd I-II. Tartu: Tartu Ülikooli Kirjastus.

L e p aj õ e, Marju 2012. Roomlaste taltsutamine. (Eesti mõttelugu 102.) Tartu: Ilmamaa.

L i i m e ts, Reet 2011. Ich als raumzeitliches Konstrukt: die Fiktionen vom Leben der estnischen und deutschen Jugendlichen. Frankfurt am Main-Berlin-BernBruxelles-New York-Oxford-Wien: Peter Lang.

L i i v, Toomas 2012. Tekst teeb oma töö. Tallinn: Eesti Keele Sihtasutus.

L u k a s, Liina 2011. Estonian Folklore as a Source of Baltic-German Poetry. Journal of Baltic Studies, nr 4, lk 491-510.

L u k a s, Liina, P l a t h, Ulrike, T ü ü r, Kadri (toim) 2011. Umweltphilosophie und Landschaftsdenken im baltischen Kulturraum. / Environmental Philosophy and Landscape Thinking. Tallinn: Underi ja Tuglase Kirjanduskeskus.

M a n d e l, Aive 2011. Eesti kirjanike loomingulised komandeeringud stalinismi ajal. - Ajalooline Ajakiri, nr 2, lk 153-187.

M a t t h e u s, Ave 2012. Eesti laste- ja noortekirjanduse genees: küsimusepüstitusi ja uurimisperspektiive. (Tallinna Ülikooli humanitaarteaduste dissertatsioonid 31.) Tallinn: Tallinna Ülikool.

M a t the us, Ave, Z a brodskaja, Anastassia (koost, toim) 2011. Noored filoloogid: kirjanduse ja keele piirimail. Tallinn: Tallinna Ülikooli eesti keele ja kultuuri instituut.

M e lt s, Brita 2012. Tänapäeva kirjandusteaduse väärikas kollaaž. - Keel ja Kirjandus, nr 5, lk 384-387.

M e r i l a i, Arne (koost) 2010. Inimesepoeg Valgel laeval: Uku Masing 100. Tartu: Eesti Kirjandusmuuseum, Tartu Ülikool.

M e ri l a i, Arne 2011a. Vokimeister: kriitilisi konstruktsioone 1990-2011. Tartu: Tartu Ülikooli Kirjastus.

Merila i, Arne 2011b. Õnne tähendus: kriitilisi emotsioone 1990-2010. Tartu: Tartu Ülikooli Kirjastus.

M e r i l a i, Arne (koost) 2012. Täiskui: Andres Ehin. Tartu: Tartu Ülikooli Kirjastus.

M e t s t e, Kristi, Un d u s k, Jaan, L e p a j õ e, Marju 2011. Friedrich Robert Faehlmann. Teosed III. Tartu: Eesti Kirjandusmuuseum, Tallinn: Underi ja Tuglase Kirjanduskeskus.

Mi h k e l e v, Anneli 2010. Kirjandusteadus Eestis 2008-2009. Dialoogid ja hägusad piirid. - Keel ja Kirjandus, nr 4, lk 280-292.

M i ki v e r, Ilmar 2010. Ankruketi lõpp: 9 esseed eesti luulest. Tallinn: Kultuurileht.

M ü h l e n, Ilse von zur (toim) 2012. Glanz und Elend: Mythos und Wirklichkeit der Herrenhäuser im Baltikum. Lindenberg im Allgäu: Fink.

N i i t, Margo, K l e m e n t, Elisabeth (koost) 2010. Vikerkaar. Amsterdam-Tallinn: Asterisk. 
O j a m a a, Ott 2010. Armastus seaduslikus abielus. Tartu: Ilmamaa.

P a r ve, Ralf 2010. Minu aeg: kirjandusloolised vestlused. Tallinn: Eesti Keele Sihtastutus.

P il d 2010 = Пильд, Леа (toim) 2010. Россия и Эстония в XX веке: диалог культур. Tartu: Tartu Ülikooli Kirjastus.

P i l t e r, Lauri 2011. Kirjanduse ajatu lugu kirjandusajalugudes. - Keel ja Kirjandus, nr 5, lk 381-384.

Pl a t h, Ulrike 2011. Esten und Deutsche in den baltischen Provinzen Russlands: Fremdheitskonstruktionen, Lebenswelten, Kolonialphantasien 1750-1850. Wiesbaden: Harrassowitz.

P o p o v, Valeri 2011. Sergei Dovlatovi ristriimid: tema 70. sünnipäeva puhul. Tallinn: Kultuurileht.

Põ ld mä e, Rudolf 2011. Vennastekoguduse kirjandus. (Eesti mõttelugu 101.) Tartu: Ilmamaa

P õ l d v e e, Aivar 2011. 17th century Estonian orthography reform, the teaching of reading and the history of ideas. - Trames: Journal of the humanities and social sciences, nr 4, lk 365-384.

P õ l t s a m - J ü r j o, Inna, T a n n b e r g, Tõnu 2011. Ideed ja ühiskond: Balti provintside mõtte- ja kultuuriloost 18.-19. sajandil. Tartu: Ajalooarhiiv.

Pä ll, Janika, V o lt, Ivo, S t e i n r ü ck, Martin (toim) 2010. Classical tradition from the 16th century to Nietzsche. (Morgensterni Seltsi toimetised 3.) Tartu: Tartu University Press.

R a u d s e p p, Hugo 2012. Nüüd ma tahan mõõka tõsta. (Eesti mõttelugu 108.) Tartu: Ilmamaa.

R e n n o, Olav 2011. Eesti kirjanduse seletav sõnaraamat. - Sakala 17. IX, lk 6.

R u m m o, Paul-Eerik 2010. Kuldnokk kõnnib: jooksvast kirjandusest 1964-2009. Tartu: Ilmamaa.

S a l u p e r e, Malle 2012. Kultuuriloolisi vaatlusi Tartu teljel. Tartu: Ilmamaa.

S a n g, Joel 2010. Espresso: valik tööhüpoteese. Tallinn: Eesti Keele Sihtasutus.

S a r a p i k, Virve, V i i r e s, Piret (koost) 2010. Sügisball. 9. juunil 2008 toimunud konverentsi „Sügisball” ettekannete ajakirjanduses ilmunud artiklid. TallinnTartu: Eesti Kirjandusmuuseumi kultuuri- ja kirjandusteooria töörühm, Tartu Ülikooli Kirjastus.

S a z o n o v, Vladimir 2010. Printsess En-hedu-Ana: Kuujumala abikaasa ja esimene luuletaja? - Akadeemia, nr 4, lk 659-670.

S c h e r r, Barry P. (toim) 2011. Formal Methods in Poetics: A Collection of Scholarly Works Dedicated to the Memory of Professor M. A. Krasnoperova. Lüdenscheid: RAM-Verlag.

Sill a o t s, Marta 2012. Kirg ja kavalus. (Eesti mõttelugu 104.) Tartu: Ilmamaa.

Z o lj a n, L o tm a n 2012 = Золян, Сурен, Лотман, Михаил 2012. Исследования в области семантической поэтики акмеизма. (Acta Universitatis Tallinnensis. Humaniora.) Таллинн: Издательство Таллиннского Университета.

T a l v e t, Jüri 2012. Juhan Liivi luule. Monograafia. Tallinn: Tänapäev.

T a m m, Marek (toim) 2011. Humanitaarteaduste metodoloogia: uusi väljavaateid. Tallinn: TLÜ kirjastus.

T a m m, Margus 2011. Mis on kollektiivne autor? - Acta Semiotica Estica, nr 8, lk 125-150.

T a r v a s, Mari 2011. Paul Fleming und das literarische Feld der Stadt Tallinn in der Frühen Neuzeit: Studien zum Sprach-, Literatur- und Kulturkontakt einer Region. Würzburg: Königshausen \& Neumann. 
T o m b e r g, Jaak 2011. Kirjanduse lepitav otstarve. Tartu: Tartu Ülikooli Kirjastus.

T o r o p, Peeter, O s i m o, Bruno 2010. Historical identity of translation: from describability to translatability of time. - Trames: Journal of the humanities and social sciences, $\mathrm{nr} 4$, lk 383-393.

U i b o p u u, Valev 2012. Välismaine Eesti Kirjanike Liit. Tallinn: Eesti Kirjanike Liit.

U n d u s k, Rein 2012. Faith and reason: Charting the medieval concept of the infinite. - Trames: Journal of the humanities and social sciences, nr 1, lk 3-45.

U n t, Kersti, U n t, Marja 2012. Seilates sadamata: omakirjastus okupeeritud Eestis. Tallinn: Varrak.

V a b a r, Sven (koost) 2011. Luhtatulek: ekslemisi Mehis Heinsaare tihnikutes. Tallinn-Tartu: Tartu Ülikooli Kirjastus.

V a h e r, Vaapo 2012. Vampiiride tants. Esseed ja ütlemised. Tallinn: Eesti Keele Sihtasutus.

V a in o, Maarja 2011. Irratsionaalsuse poeetika A. H. Tammsaare loomingus. (Tallinna Ülikooli humanitaarteaduste dissertatsioonid 26.) Tallinn: Tallinna Ülikool.

Vdovin 2011 = Вдовин, Алексей 2011. Концепт „глава литературы” в русской критике 1830-1860-х годов. Tartu: Tartu Ülikooli Kirjastus.

V e i d e m a n n, Rein 2010. Eksistentsiaalne Eesti: käsitlusi eesti kirjandusest ja kultuurist 2005-2010. Tallinn: Tänapäev.

V e i d e m a n n, Rein 2011. 101 Eesti kirjandusteost. Tallinn: Varrak.

V e i d e m a n n, Rein, K e p p, Õnne (koost) 2011. Kõnetav kultuur. Tallinn: Eesti Keele Sihtasutus.

V e t e m a a, Enn 2012. Mees nagu saksofon. Tallinn: Tänapäev.

V i i t o l, Livia 2012. Eduard Vilde. Tallinn: Tänapäev.

W e 1 l e k, René, W a r r e n, Austin 2010. Kirjandusteooria. Tartu: Ilmamaa.

Õ n n e p a l u, Tõnu 2011. Ainus armastus: valik esseid. Tallinn: Varrak.

\section{The Past Triennial of Estonian Literary Studies: a Database Based Survey}

Keywords: Estonian, literary studies, annual overviews, databases, indexing, open access

Monitoring the state of the art in national research is a necessary autocommunication mechanism of a culture. The present overview surveys the monographs, collections, and research articles concerning Estonian literature, which have been published during the period of 2010-2012. The overview is based on the databases ESTER and ISE of the Estonian Libraries Network Consortium. The Estonian subject thesaurus and UDC classificators were used for finding the publications classified as 'literary studies'. An additional survey was carried out among those articles published in Estonian literary periodicals that were not indexed as 'literary studies'. The main quantitative findings of our research are that ca 70 books and ca 500 articles were published on the subject of literary research related with Estonian material during the past three-year period. The publications were issued not only in Estonia, but in Germany, Russia, Finland, Lithuania and France, while the array of the languages of research was also diverse. Article collections published in the framework of inter- 
institutional co-operation appear to stimulate scholarly communication, whereas single articles in selected high-rating journals may not be accessible for the wider community of readers interested in studies on Estonian literature. Open access to scholarly work in online environments is of crucial importance.

Kadri Tüür (b. 1975), MA, University of Tartu, researcher; Estonian Literary Museum, project manager; doctoral student at the Department of Semiotics, Institute of Philosophy and Semiotics, University of Tartu, tyyr@ut.ee

Elle-Mari Talivee (b. 1974), MA, Under and Tuglas Literature Centre of the Estonian Academy of Sciences, researcher; doctoral student at the Estonian Institute of Humanities, Tallinn University, ellemari@utkk.ee 